\title{
WORK AND PERSONAL LIFE: WHICH STRATEGIES DO SECONDARY SCHOOL EDUCATORS USE TO DEAL WITH THE INTERACTION?
}

Authors:

Lizelle Wentzel ${ }^{1}$

Chenell Buys ${ }^{1}$

Karina Mostert

\section{Affiliations:}

${ }^{1}$ Faculty of Economic and

Management Sciences,

North-West University,

South Africa

\section{Correspondence to:}

Karina Mostert

e-mail:

karina.mostert@nwu.ac.za

\section{Keywords:}

work; personal life

interaction; strategies;

secondary school educators

\section{Dates:}

Received: 25 Sep. 2008

Accepted: 10 Jan. 2009

Published: 30 May 2009

How to cite this article:

Wentzel, L., Buys, C., \&

Mostert, K. (2009). Work

and personal life: Which

strategies do secondary

school educators use to deal

with the interaction? $S A$

Journal of Human Resource

Mangement/SA Tydskrif vir

Menslikehulpbronbestuur,

7(1), Art. \#166, 9 pages. DOI:

10.4102/sajhrm.v7i1.166

\section{This article is available} at:

http://www.sajhrm.co.za

(C) 2009. The Authors.

Licensee: OpenJournals

Publishing. This work

is licensed under the

Creative Commons

Attribution License.

\section{ABSTRACT}

The general objective of this study was to investigate which strategies secondary school educators use to deal with the interaction between their work and personal lives. A nonprobability purposive voluntary sample $(N=21)$ was taken of secondary school educators from the Potchefstroom and Promosa areas in the North West Province. Data was collected through a phenomenological method of semi-structured in-depth interviews and was analysed by the use of content analysis. Strategies that were reported by the educators included support and understanding from important others, work satisfaction, keeping work and personal life apart, acceptance of their teaching environment, planning ahead, experiencing teaching as a calling, experience in the educational field, communication, religion or prayer, doing exercise and staying active, and doing the work that is expected of them.

\section{INTRODUCTION}

Education plays a fundamental role in South Africa, where a high premium is set on accomplishing a range of critical objectives such as social transformation, technological innovation and individual empowerment. Subsequently, increasing pressure is placed on education to contribute its share towards meeting the social demands originating from the pursuit of those objectives (Marais \& Meier, 2004). In addition, education provides a learner with new skills and knowledge that must enable him or her to function in a modern society. Furthermore, education has been considered as an instrument for illuminating structures of oppression and providing learners with the tools to amend those oppressive structures in society (Vandeyar, 2003).

Recently, the idea of teachers experiencing excessive stress has received deserved attention. Stress and burnout among educators have also become much talked about phenomena and have increasingly been acknowledged as widespread problems and global concerns (Jackson \& Rothmann, 2006; Montgomery, Mostert \& Jackson, 2005a). As the demands on educators and schools increase, so does the incidence of stress in the teaching profession (Shulze \& Steyn, 2007). It has also been shown that teacher stress is related to many different work outcomes, such as turnover intentions, job performance and job satisfaction (Geving, 2007). In addition, the stress that educators experience can have serious implications for their physical and mental health. Today, many teachers complain about low morale and stress-related illnesses such as hypertension, diabetes, ulcers and heart attacks, whereas others plan to leave the profession and take early retirement (Olivier \& Venter, 2003)

The new political dispensation that has been taking place in South Africa since the first democratic elections in 1994 gave rise to the socio-cultural and socio-economic transformation taking place today (Horn, 2006). Educational structures within the South African context are influenced by this transformation and increased demands are being placed on educators (Montgomery et al., 2005a). Educators must cope with demands such as increased specialisation, the growing scope of syllabuses, lack of discipline in schools, the abolishment of corporal punishment, unmotivated learners, learners' negative attitudes towards themselves, redeployment, retrenchments (right-sizing) and retirement packages for teachers, large pupil-teacher ratios and a new curriculum approach (Niehaus, Myburgh \& Kok, 1996; Olivier \& Venter, 2003; Schulze \& Steyn, 2007). Moreover, the new Outcomes-based Education (OBE) approach, the management style of principals, new governing bodies for schools, the high crime rate in the country, coping with current political change and corruption in state departments are all contributing to the increased demands that are being placed on educators (Marais, 1992).

These problems manifest in various forms of destructive behaviour such as alcohol abuse, absenteeism, difficulties in setting priorities in their work and personal lives and destructive relations between educators and learners, educators and colleagues and educators and their families (Myburgh \& Poggenpoel, 2002; Van Wyk, 2004). This ultimately results in poor quality of life (Van Wyk, 2004). Therefore, it seems important and relevant to investigate not only the work lives of teachers, but also their personal lives and the interaction between these two domains.

The relationship between work life and personal life is an issue that now commands growing attention in both the public and private sectors. All things considered, work and family (personal) life are the two domains of human activity in which fully employed individuals spend about two-thirds of their time (one-third in each). The essence of the relationship between work life and family life today is that the two domains overlap and interact (Nollen, 1986). This interaction is increasing due to changes in family structures (e.g. single parents, dual-career couples and fathers heavily involved in parenting), increased participation by women in the labour force, and technological changes (e.g. mobile phones and portable computers) that enable job tasks to be performed in a variety of locations (Carnicer, Sánchez \& Pérez, 2004; Hill, Miller, Weiner \& Colihan, 1998). In addition, psychological and physical boundaries between work and personal life have become more blurred as organisations become increasingly virtual and more people work at or from home for all or part of the week using information and communication technologies (Montgomery, Panagopoulou, Peeters \& Schaufeli, 2005b). Consequently, work and family roles have gradually become more intertwined and men and 
women are increasingly concerned about managing the conflict experienced in fulfilling the dual demands and responsibilities of work and family roles (Montgomery et al., 2005b; O'Driscoll, Brough \& Kalliath, 2004).

For many workers, this has created the potential for interference or conflict to occur between their work and family lives (Hil et al., 1998). Previous research indicates that in some instances work interferes with family life (work-to-family conflict), and in other situations family responsibilities interfere with life at work (family-to-work conflict) (Eby, Casper, Lockwood, Bordeaux \& Brinleya, 2005). Greenhaus and Beuttell (1985) describe work-family conflict as a form of inter-role conflict in which responsibilities from the work and family domains are not compatible. Furthermore, work-family conflict has been shown to have an unfavourable relation with a variety of variables associated with employee work life, home life, and general health and well-being. Greater health risks for working parents, lowered performance in the parental role, lowered productivity at work, less life satisfaction, anxiety and work stress are all variables that can be associated with the unfavourable experience of workfamily conflict (Allen, Herst, Bruck \& Sutton, 2000; Greenhaus \& Beutell, 1985; Kelly \& Voydanoff, 1985; Kossek \& Ozeki, 1998 ; Small \& Riley, 1990). It would therefore seem reasonable that the conflict between the work and family domains is of increasing concern in today's organisational environment (Howard, Donofrio \& Boles, 2004).

Duxbury (2004) stresses the importance of using coping strategies to efficiently deal with work-life issues. To attain good work-personal life interaction (WPLI), coping strategies have to be integrated by the individuals themselves as well as by the organisation. The organisational initiatives being promoted to assist employees to cope with work and personal life have a tendency to be discussed under the general rubric of familyfriendly organisational policies or reimbursement (Frone, 2003). The literature has focused on the ways that organisations can 'manage the situation' by generating flexible working policies or arrangements (Rotondo, Carlson \& Kincaid, 2002). Such flexibility is, obviously, a possible means of reducing stress linked with work-family conflict (Warren \& Johnson, 1995). However, such policies and arrangements are still not available to everybody. Several employees, particularly those working in smaller organisations, do not enjoy benefits like flexitime, on-site day care, career-break schemes, and informal support networks (Rotondo et al., 2002)

The capacity to cope with the stress created from the instantaneous demands of work and family is often a function of the capabilities of the individual (Rotondo et al., 2002). The ways people cope with stress and daily living also influence their psychological, physical and social well-being (Pienaar \& Rothmann, 2003). Furthermore, work-related stress is rather serious among secondary school educators, threatens their health, and affects work behaviour and performance (Pei \& Guoli, 2007). A study by Schulze and Steyn (2007) among secondary school educators indicated that individual educators have to accept the responsibility to acquire coping skills to deal efficiently with the demands of the occupation. With this in mind, it is significant to note that being a secondary school educator is one of the ten toughest professions in South Africa and therefore it is necessary to develop appropriate programmes to help educators develop coping skills (Schulze \& Steyn, 2007) Hence, in light of the above discussion, the objective of this study is to determine which strategies secondary school educators use to deal with WPLI issues.

\section{Work-personal life interaction}

Over the past 25 years, researchers, social commentators, organisational managers and people in general have expressed considerable concern about work-family issues ( $\mathrm{O}^{\prime}$ Driscoll et al., 2004). In most studies, work and family are regarded as two conflicting domains - work conflicts with family and family conflicts with work (Mostert, 2006). As a result, the most widely referred to definition of work-family conflict is that of Greenhaus and Beutell (1985, p. 77), which states that work-family conflict is 'a form of inter-role conflict in which the role pressures from the work and family domains are mutually incompatible in some respect. That is, participation in the work (family) role is made more difficult by virtue of participation in the family (work) role'. This definition implies a bi-directional dimension in that work can interfere with home (work-home interference; WHI) and that home can interfere with work (home-work interference, HWI) (Frone, 2003). Furthermore, Greenhaus and Beutell (1985) outlined three distinct forms of work-family conflict, including time-based conflict (i.e. incompatible time demands between work and family), strain-based conflict (e.g. affective overspill from one domain to the other), and behaviour-based conflict (e.g. where in-role behaviour in one domain is incompatible with role behaviour in the other domain).

Common antecedents of WPLI include gender, family status, work involvement and work demands. Women, individuals with children, more highly job involved individuals and individuals experiencing greater job demands typically report more negative interaction between their work and personal lives (Burke, 2004). According to Demerouti, Geurts and Kompier (2004b), research findings consistently support that work characteristics are mainly antecedents of negative influence from work, and that home characteristics are the major antecedents of negative influence from the personal life domain. On the other hand, consequences of WPLI can be grouped into two categories: those dealing with attitudes regarding job and family life (e.g. satisfaction), and those which signify some aspect of well-being (such as psychological strain or physical health). Research evidence is consistent and overwhelming - a perception that work and family life interfere with each other is associated with dissatisfaction with both the job and personal life, along with reduced feelings of well-being (or, conversely, heightened psychological and physical strain) (O'Driscoll et al., 2004).

\section{Coping}

A wide range of coping strategies exist, and the most common and widespread coping taxonomy was proposed by Lazarus and Folkman (1984). These authors define coping as the cognitive and behavioural efforts individuals use to manage taxing demands appraised as exceeding their personal resources. They suggest that coping has two main functions: the regulation of distressing emotions (emotion-focused coping) and doing something to positively change the problem causing the distress (problemfocused coping). Problem-focused coping refers to efforts directed at doing something productive about the conditions that harm, threaten or challenge, or to change or manage the type of stress (Shaw, 1999). These include, for instance, active coping such as eliciting instrumental social support, drawing on work flexibility and planning and the suppression of competing activities. Emotion-focused coping refers to efforts aimed at regulating the emotion itself, or reducing psychological distress in order to help sustain equilibrium (Aldwin \& Revenson, 1987). Such strategies include focusing on and venting emotions, mental disengagement, positive reassessment, acceptance and denial (Steward \& Donald, 2006). Also, Folkman and Lazarus (1988) found that people used considerably less planful problemsolving and distancing in situations that involved concern for a loved one's well-being and that more planful problem-solving and self-control were used in situations that involved a goal at work.

Endler and Parker (1990) acknowledge that the third basic strategy that may be used in coping with stress is avoidance. Avoidance can include either person-oriented or task-oriented strategies. Avoidance differs from problem- and emotion-focused coping in that avoiding a situation actually removes the person from the stressful situation, whereas problem- and emotion-focused coping may help the person deal with the stressful situation while 
he or she remains in it (Kowalski \& Crocker, 2001). Additionally, an avenue that is in need of investigation is the coping process through which individuals deal with work-family conflict. It may be that certain types of coping mechanisms are used more frequently and effectively by some groups rather than others (Carlson \& Kacmar, 2000). A more recent study conducted by Toth (2005) among managers in a multinational corporation in Hungary found that men and women have different views of work-life balance and adopt different coping strategies to deal with work and family commitments. It was generally found that work-life balance is constructed as an individual, rather than a corporate responsibility and this also generates gendered inequalities. Furthermore, Crooker, Smith and Tabak (2002) state that chosen coping behaviours or reaction patterns are a function of individual differences such as personality types, individual resourcefulness, or attitudes and beliefs. Crooker, Smith and Tabak (2002) also mention that diverse personalities cope with uncertainty in different ways, determining experienced worklife balance as well as individual outcomes such as stress levels and organisational outcomes such as work behaviours.

Additionally, research by Brink and De la Rey (2001) found that South African businesswomen make use of both emotional and problem-focused coping strategies to deal with workfamily conflict. These strategies include positive reappraisal, planful problem solving, exercising self-control and seeking social support. They also found that women who use cognitive appraisal (control) as a coping strategy are less likely to choose escape-avoidance as a coping strategy to manage the situation. Findings of a research project undertaken by Rotondo et al. (2002) investigate the effectiveness of different coping styles to deal with work-family conflict. They found that avoidance/ resignation coping is associated with higher levels of workfamily conflict, and help-seeking and direct action coping tools used at home were associated with lower family-work conflict. Also, in a more recent study by Steward and Donald (2006) it was shown that spouses whose partners are absent due to frequent business travel use both problem- and emotion-focused coping to deal with their partners' absence. The main coping resources that the spouses made use of included work flexibility and social support.

According to Carlson and Perrewe (1999), social support may be an imperative coping mechanism against the strain of workfamily conflict through its impact on perceived stressors. This proposes that individuals who develop strong social support networks at work and at home may in reality perceive fewer stressors in their organisational and family life. Also, social support has been suggested to moderate the consequences of work-family role conflict on the well-being of dual-career couples (Kirrane \& Buckley, 2004).

Other aspects of coping behaviour have been studied by Beutell and Greenhaus (1983), who found that tradition-oriented women tend to adopt non-functional coping strategies when dealing with intense work-family conflict. Also, in a study done by Beehr, Johnson, Nieva and Hurrel (1995) among 177 police officers and their spouses it was found that emotion-focused coping (e.g. putting the situation in perspective) was effective in reducing many of the strains reported by police officers. Also, it was found that police officers' use of religion as a coping strategy may be beneficial for their spouses. In a study done by Matsui, Ohsawa and Onglatco (1995), it was found that family role definition (i.e. re-negotiating role expectations, altering one's attitudes and viewpoints about role expectations) was an efficient coping strategy for dealing with family-to-work overspill among Japanese working women.

Furthermore, research by Edwards and Rothbard (2000) suggests that the active separation of work and family may also be seen as a way of coping with stress from either domain, or as a way of maintaining a preferred degree of connection between work and family. In addition to the aforementioned, a study by Wallis and
TABLE 1

Characteristics of the participants

\begin{tabular}{|c|c|c|c|}
\hline ITEM & CATEGORY & FREQUENCY & $\begin{array}{r}\text { PERCENTAGE } \\
(\%)\end{array}$ \\
\hline \multirow[t]{2}{*}{ Gender } & Male & 7 & 33.3 \\
\hline & Female & 14 & 66.7 \\
\hline \multirow[t]{4}{*}{ Age } & $20-29$ years & 1 & 4.8 \\
\hline & $30-39$ years & 12 & 57.1 \\
\hline & $40-49$ years & 5 & 23.8 \\
\hline & $50-69$ years & 3 & 14.3 \\
\hline \multirow[t]{3}{*}{ Race } & White & 7 & 33.3 \\
\hline & Coloured & 4 & 19.0 \\
\hline & African & 10 & 47.6 \\
\hline \multirow[t]{6}{*}{ Qualification } & University degree & 6 & 28.6 \\
\hline & Postgraduate degree & 7 & 33.3 \\
\hline & Technicon diploma & 2 & 9.5 \\
\hline & Technical college & 2 & 9.5 \\
\hline & Other & 3 & 14.3 \\
\hline & & & \\
\hline \multirow[t]{2}{*}{ Marital status } & Married & 15 & 71.4 \\
\hline & Not married & 6 & 28.6 \\
\hline \multirow[t]{5}{*}{ Parental status } & No children & 1 & 4.8 \\
\hline & One child & 4 & 19.0 \\
\hline & Two children & 10 & 47.7 \\
\hline & Three children & 5 & 23.8 \\
\hline & Four children & 1 & 4.8 \\
\hline \multirow{4}{*}{$\begin{array}{l}\text { Teaching } \\
\text { experience }\end{array}$} & $2-9$ years & 5 & 23.8 \\
\hline & $10-19$ years & 11 & 52.4 \\
\hline & $20-29$ years & 3 & 14.3 \\
\hline & $30-39$ years & 2 & 9.5 \\
\hline
\end{tabular}

Price (2003) amongst a group of twenty single working mothers with pre-school age children found that nine of the women in this sample tried to reduce conflict between work and family by separating the two via segmentation, whereby each domain is kept separate in terms of time, physical location, attitudes and behaviour. Moreover, there is some evidence that effective coping responses to work-family conflict can eradicate or lessen both job-related and home distress (Lazarus \& Folkman, 1984). However, there is still a limited amount of research in the field of Occupational Health Psychology regarding the relationship between coping and work-home interaction.

\section{RESEARCH DESIGN}

\section{Research approach}

A qualitative design from a phenomenological approach was used. In this approach, the researchers were interested in the meaning educators attributed to their experiences of reality, their world and their relationships. The educators' cognitive experiences had to be understood and defined because it was only through that that the true essence of the educators' experience could be realised (Rothmann, Gerber, Lubbe, Sieberhagen \& Rothmann, 1998). 


\section{Research strategy}

The study's unit of analysis was individual educators and the case study as a familiar design was chosen. The study comprised of multiple case studies within the context of a more distinct exploratory approach. A sample size of 21 secondary school educators was chosen. Furthermore, both the first and second researcher approached the secondary school educators to share their stories and experiences. Descriptive information of the sample is given in Table 1.

As can be seen in Table 1, the participants were predominantly female $(66.7 \%)$. In total, $47.6 \%$ were African, $33.3 \%$ were White and $19.0 \%$ were Coloured. Most of the participants were between the ages of 30-39 years (57.1\%). Regarding marital status, $71.4 \%$ of the participants were married, and $47.7 \%$ of the participants had two children. More than half of the participants $(52.4 \%)$ had been teaching for $10-19$ years.

\section{RESEARCH METHOD}

\section{Research setting}

The interview was held in a relaxed environment (e.g. classrooms and homes) where attention was given to the climate and atmosphere of the room. Where necessary, and in order to ensure that the interview was not interrupted, a 'do not disturb' sign was placed outside the door. Ensuring that the participant was at ease, the researchers introduced themselves in a friendly and warm manner and explained the context of the interview.

\section{Entrée and establishing researcher role}

Consent to conduct the research was received from the Department of Education and participating schools. The headmasters of the respective schools acted as mediators and were provided with information about the research project, as well as with the selection criteria for the identification of possible participants. The headmasters provided the researchers with the names and contact details of educators willing to participate. Criteria for inclusion in this research were educators who 1) were working in the selected schools in the Potchefstroom and Promosa area; 2) had at least two years' work experience; and 3) were willing to participate in the research and prepared to have a tape-recorded interview with the researchers. The possible participants were contacted and interviews were scheduled with them. Of these participants, 21 were interviewed, after which the data was saturated (Woods \& Catanzaro, 1988).

\section{Sampling}

The population consisted of a non-probability purposive voluntary sample of secondary school educators in the Potchefstroom and Promosa area $(N=21)$.

\section{Data collection methods}

A semi-structured interview, based on the phenomenological paradigm was used in this research. The researchers studied the phenomenon without predetermined expectations of categories and tried to understand the data from the perspective of the participant. The interview was informal and non-directive, with the central question: 'You have a work life and a personal life. Can you tell me which strategies you use to deal with the interaction between these two domains?'. The researchers asked the question and made sure that the participants understood the question.

A pilot study was carried out to improve the success and effectiveness of the investigation (De Vos, Strydom, Fouché, Poggenpoel \& Schurink, 1998). The pilot study assisted the researchers in making the necessary modifications of the datagathering instrument. The interview schedule was evaluated by an expert for appropriateness before the main investigation proceeded. The pilot study also ensured that the researchers were able to use non-directive dialogue techniques. The researchers faced the participant squarely in a relaxed way, had an open body posture and leaned slightly forward to ensure that the participant was comfortable during the whole interview. The researchers also kept eye contact with the participant at all times. Non-directive dialogue techniques like minimal verbal responses (e.g. 'mm-mm, yes, I see'), paraphrasing (stating the participant's words in another form with the same meaning), clarification (e.g. 'Can you tell me more about...' 'You seem to be saying...'), reflection (e.g. 'So, you believe that...'), reflective summary (e.g. 'So what you're saying...') and silence were used to assist the participants to share their experiences. Socialdesirable responses were also minimised by making use of these dialogue techniques. Rephrasing and repetition of questions were used in order to gain credibility of information. The researchers strived to promote validity by spending enough time with the participant in order to establish a rapport. Immediately after each interview, the field notes regarding that interview were written down. The field notes included both the empirical observation and interpretations. The researchers wrote down their emotions, preconceptions, expectations and prejudices so that they could be developed in the final product.

\section{Recording of data}

The interview was tape-recorded with the permission of the participant and it was also emphasised that the identity of the participant would remain anonymous and that the participant could withdraw from the study at any time.

\section{Data analysis}

The interviews were transcribed verbatim and then coded by the researchers by means of content analysis. Content analysis consists of various steps (Giorgi, 1985; Kerlinger, 1986). Firstly, the content that needed to be analysed was universalised, defined and categorised. Secondly, the sub-units, namely words and themes of the analysis, were determined. The researchers read the responded notes in order to form an overall picture. Afterwards, the researchers once again read the notes in order to determine the themes. The words that were used by the participant were the smallest analysis that was made. A sub-theme is usually a sentence and is more difficult but also more useful to analyse. Sub-themes were combined in order to determine the themes. The analysis of the information was continued until repeated themes were identified. Thirdly, the data was cleared of unnecessary information and the meaning of the rest of the sub-units was determined by linking it to the whole picture. Lastly, the concrete language of the participants was converted into scientific language and concepts. The precise words of the participants were used in support, based on gained insights, integration and synthesis.

The number of objects per category was counted and placed in order of preference. The trustworthiness of the content analysis was promoted by the coding that was done by the researchers and a co-coder. A literature-control was done to investigate relevant research in order to determine the comparativeness and uniqueness of the current research (Krefting, 1991).

\section{Strategies to enhance the quality of data}

Guba's model for qualitative research (Guba, 1981; Krefting, 1991; Lincoln \& Guba, 1985) was applied in order to ensure the trustworthiness of the findings. Attention was given to the principles of credibility (checking the truth value of the findings), by means of field notes, triangulation, peer examination and independent coding; transferability (ensuring applicability of the findings), through comparison of sufficient descriptive data, as well as dense description of the data; dependability (ensuring consistency of the findings), by means of an audit, keeping of the raw material, giving a full description of the research method, applying the same procedure throughout, triangulation, peer examination and the code-recode procedure; conformability (which was accomplished by using the criterion of neutrality or freedom from bias), by keeping an appropriate distance in order not to influence the research, as well as triangulation and the code-recode procedure. 
Also, conducting research is an ethical enterprise. Research ethics provide researchers with a code of moral guidelines on how to conduct research in a morally acceptable way. The following was applied at all times to retain an ethical climate (Struwig \& Stead, 2001): The researchers were honest, fair and respectful towards the participants and did not attempt to mislead or deceive the research participants. The researchers respected the rights and dignity of others. This included respecting the privacy, confidentiality and autonomy of the research participants. The researchers were also mindful to cultural and individual differences among people, such as age, gender, race, ethnicity, religion, language and socio-economic status. The researchers therefore did not knowingly discriminate against people based on such factors. The welfare of others was a major concern. The researchers avoided or minimised any harm befalling the research participant as a result of interaction with them.

The major themes that emerged from the data were discussed and enforced by quotations from participants. Where necessary, quotations were adapted to read without effort and to make more sense.

\section{RESULTS}

The findings of this study were organised into major themes concerning the strategies that educators use to cope with the interaction between work and personal life. Table 2 shows the themes and the frequency of the responses for male and female participants, as well as the frequency that the theme was mentioned for the total group.

Educators experienced certain aspects that helped them to deal with the interaction between their demanding work environment and personal lives. The various strategies that they made use of are discussed next.

\section{Theme 1: Support and understanding from important} others

One aspect that was found to facilitate educators' interaction between their work and personal lives was support and understanding from people in their work environment (e.g. headmaster and colleagues), as well as people in their personal lives (e.g. spouses, partners, family and friends). Support and understanding from people in the work environment was prominent in the following responses: 'We (educators) are a small group, but we can also support each other'; 'If one of us decides to study further, then our colleagues help us, they go out of their way to help and support us'.

Reasons why educators viewed their spouse as supportive included that the spouses knew what responsibilities teaching entailed and helped with duties at home such as cooking and caring for children: 'Fortunately my husband knows how to cook, even when I had the babies he helped me feed the child and I had his support.' Furthermore, the support educators experience from their spouses was sometimes from spouses in the same field of work (education): 'When an educator is married to another educator it makes the house circumstances a lot better. They know the same daily routine, programme and a person understands each other's circumstances better'; 'My husband is also in education, which makes it easier'. The perception was that spouses understood the educational circumstances and gave advice or assisted with the workload.

\section{Theme 2: Work satisfaction}

The interviews also indicated that educators' work satisfaction facilitated the interaction between work and family life. One of the participants indicated: 'I enjoy it incredibly, I am mad about education and I like children'. This suggested that educators experienced work satisfaction because of their fondness of education, teaching and working with children. Some of the educators also indicated that they enjoyed the subjects that they taught at school: '... I enjoy teaching and I enjoy my subject...'. Other educators were of the opinion that money does not matter and that one should not be in education for the money, seeing that it is a well-known fact that educators are poorly remunerated: 'I am one of the lucky ones that are happy and satisfied and money is not everything to $\mathrm{me}^{\prime}$. As a result, educators' work satisfaction seemed to help the interaction between their work (demanding work environment) and their personal lives.

\section{Theme 3: Keeping work and personal life apart}

Some of the participants revealed that they deal with the interaction between their work and personal lives by actively trying to keep work and personal life apart. In was clear from the interviews that the educators tried to keep work and personal life apart by finishing their work at school and not taking it home. Also, they tried not to let work problems interfere with their home situation and vice versa: 'If a thing happens here (school) no matter what it is, I don't take it home. Certain things that happen here have nothing to do with my family'; '...when I have problems at home I will never bring them to work...'; '... when I leave work I leave the ones at work and I concentrate on the ones at home because if I cluster them together they are going to frustrate and confuse me'. In other words, work and personal life were viewed as two separate spheres. Therefore, problems that could exist between these two spheres are reduced by keeping the spheres apart.

\section{Theme 4: Acceptance of the teaching environment}

Educators also stated that they got used to the teaching environment and accepted the educational circumstances. The participants stated: 'A person get [sic] used to the situation here. At this stage it doesn't bother you anymore'; 'It is almost part of our job description, you take it as it comes, basically'. One of the participants indicated that one has to make education

TABLE 2

Major strategies that educators use to deal with the interaction between work and personal life

\begin{tabular}{lcc}
\hline MAJOR THEMES & $\begin{array}{c}\text { FREQUENCY OF MALE } \\
\text { RESPONSES }\end{array}$ & $\begin{array}{c}\text { FREQUENCY OF FEMALE } \\
\text { RESPONSES }\end{array}$ \\
\hline 1. Support and understanding from important others & 3 & 7 \\
2. Work satisfaction & 3 & 5 \\
3. Keeping work and personal life apart & 4 & 3 \\
4. Acceptance of the teaching environment & 2 & 4 \\
5. Planning ahead & 0 & 5 \\
6. Teaching as a calling & 1 & 4 \\
7. Experience & 2 & 5 \\
8. Communication & 2 & 2 \\
9. Religion or prayer & 1 & 2 \\
10. Partaking in exercise and staying active & 0 & 3 \\
11. Doing the work that is expected of you & 0 & 3 \\
\hline
\end{tabular}


part of your personal life: 'You have to make this work part of your personal life, and when you have decided this, you have to accept it'. Another participant was of the opinion that not only do you have to accept the teaching environment, but it makes the interaction easier if your family accept it as well: 'I am married to the school. Luckily my family have accepted this'.

\section{Theme 5: Planning ahead}

Apart from the abovementioned, educators also perceived planning ahead to be tremendously important. 'A person must do good planning. This is how you cope in your house and your personal life and with all your children and with all your schoolwork, to handle everything you must do good planning'; 'So, you plan your stuff to fit in with your personal life and your personal life to fit in with your work life'. According to one of the educators planning ahead is all about managing one's time efficiently and finding a balance: '... you must plan your time incredibly well, otherwise your work accumulates and comes down all at once. You must find that balance'.

\section{Theme 6: Teaching as a calling}

Also contributing to the aspect of work satisfaction was educators' experience of teaching as a calling: 'Teaching is not an occupation, it is a calling'; 'I would not have been in education if it wasn't a calling'. Because educators perceived teaching as a calling they also stated that their salaries were of little importance. What was deemed of importance was the intrinsic motivation from the children (feelings of helping them succeed). The following quotations related to this: "The salary is not much but it is not what teaching is about'; 'The only place that you get something back is from the children'; 'The nice thing about it al is that when one of them finished studying or if they go studying and they come and show you that they are accepted... That is for me in itself the acknowledgement as educator'.

\section{Theme 7: Experience}

The educators also indicated that experience helped them to cope with demanding aspects of their work. Educators' experience allowed them to collect material aids and gain knowledge and learning experience in their subjects to help cope with the demanding aspects of their work environment. Participants made the following remarks: 'Because of longer experience, we have empathy with others that we see cannot handle it'; 'I have a whole bank of tests and exam papers that a person builds up through the years, which you use and then change a little'; 'If you have been teaching for a few years you build up a basis...' One of the respondents mentioned that because he has been in education for so many years he has to do minimal preparation for his classes: 'I have been in education so long ... I do the minimum work at home because I know my subject so well that I do not have to do preparation'.

\section{Theme 8: Communication}

It was found that educators believed that communication was very important, and that it helps to talk to someone when you experience problems at either work or home. People that educators talked to included a spouse or partner, principal and pastor: '... I know where to go. We have the principal and the deputies. If there is something that is not going well I go to them and at home it's my husband. I even taught the children to talk because if you keep quiet you are not solving anything ...'; '... I talk to my fiancée, and he also helps me.....and he gives me advice'. One of the educators even pointed out that she watches educational television shows that help her cope with the interaction between her work and personal lives: '...I watch Oprah and Dr. Phil and their programmes helps [sic] me to cope...'.

\section{Theme 9: Religion or prayer}

It also became evident during the research that educators relied on their religion to help them with the problems that they were experiencing. When times were tough, they prayed and believed that everything would get better. Statements that reflected this finding include: 'Praying ... I pray to God, that's my only tool. I pray and God helps me to believe that I am a Christian and I am born again...'; '...I pray and talk to God when I have stress...'. Moreover, educators not only prayed for themselves and for their problems but they also prayed for the children at school: 'So when I have problems with the children at school I pray for them and I believe that God can hear us and that He answers. It's important to go to church, to believe that God is there'.

\section{Theme 10: Exercising and staying active}

One of the educators mentioned that she enjoyed going to the gym after school and that this relieved her of her stress: 'When I come home from school with a lot of stress, I go to the gym and when I come back I am fine'. Another teacher reported that staying active and keeping busy helped: 'I love to keep busy and I don't like just sitting down. I am active and it helps me...'

\section{Theme 11: Doing the work that is expected of you}

It also seemed that actively finishing the work that should be completed contributed significantly to feeling less stressed: '... if you experience a heavy workload it is better to start doing the work. When I am not overloaded with work, I don't have stress. When I have a lot of work in front of me, I feel stressed, but if I finish the work the stress decreases'.

\section{DISCUSSION}

Despite their short working days and unrivalled holidays, almost half of all educators who retire on health grounds cite psychological problems caused by the pressure of work. Trade unions declare that research proves that teaching is one of the most stressful occupations in South Africa (Tighe, 2007). However, not only do educators experience demands in their work lives, but in their personal lives as well. According to Rotondo et al. (2002), managing these competing demands from the work and family domains causes formidable stress for many employees; stress which, in turn, can lead to health risks and other unpleasant outcomes. Research shows that the eradication of distress is mainly achieved through effective coping strategies (Lazarus \& Folkman, 1984). The chronic nature of most contemporary stressors (like work-family conflict) requires individuals to constantly cope in order to ease the distress.

In light of the above, the objective of this study was to investigate which strategies secondary school educators use to deal with the interaction between their work and personal lives. Various strategies were reported by the educators. Firstly, it became evident during the interviews that support and understanding from important others (e.g. headmaster, colleagues and spouse) helped educators to deal with interaction issues. Similar to the findings of Grzywacz and Marks (2000), respondents indicated that their social support at the workplace and support from their spouses seemed to contribute to positive interaction between both domains. Other authors have also found that social support from supervisors and partners is of great importance in reducing work-family conflict due to work stress and involvement (Carnicer et al., 2004). It has also been well-documented that the role of social support at work improves employees' health and well-being. In particular, supervisor support has been found to facilitate employee job satisfaction, staff development, on-thejob learning and organisational commitment (Kirrane \& Buckley, 2004). Consistent with this reasoning, it was found that social support was also viewed as a significant resource that could promote effective coping and enhance employee well-being in the face of work-personal life stress (Repetti, 1989; Weiss, 1990). Consequently, this support from work and family could reduce demanding aspects of a job and simultaneously increase their willingness to do so (Demerouti, Geurts, Bakker \& Euwema, 2004c)

Work satisfaction was another aspect that was mentioned by the educators. However, Geurts and Dikkers (2002) found that among the attitudinal consequences, job satisfaction is most 
frequently related to work-family conflict. Also, many of the educators stated that keeping their work and personal life apart was beneficial in dealing with WPLI issues. According to Lewis and Cooper (2005), some employees can integrate or harmonise their work and personal lives by deciding to keep them fairly separate. Additionally, according to Montgomery et al. (2005b), these educators follow a segregation-style of interaction since they arrange their lives in such a way that home and work are two distinct domains. From the interviews it could be seen that educators perceived this segregation-style as helping them to deal with the interaction between their work and personal lives.

In addition to the aforementioned, the respondents also mentioned experiencing teaching as a calling as another strategy. Apart from experiencing teaching as a calling, educators perceived acceptance of the teaching environment to be an essential part of facilitating work and personal life. According to Kirchmeyer (1993), strategies that aim to alter one's own attitude about what demands can reasonably be met in both domains seem to be more efficient in coping with high demands from both domains than strategies that aim to alter the attitudes or behaviours of others. Educators also viewed planning ahead to be useful in dealing with WPLI. Literature confirms this finding. According to Shaw (1999), planning can be seen as a problemfocused coping strategy. Furthermore, according to Lazarus and Folkman (1984), problem-focused coping strategies intend to deal actively with the problem. Also, Mostert and Oosthuizen (2006) found that problem-solving coping predicts lower levels of negative work-home interference. Some of the educators also mentioned communication (e.g. talking to one's spouse, pastor and partner) as another useful way to cope with WPLI issues. Moreover, religion and prayer was a different aspect that was mentioned by the educators. Literature also supports this finding. A study by Beehr et al. (1995) studied the use of coping strategies and found that police officers used religion as a coping strategy to deal with both work and non-work strain. Lastly, partaking in exercise and staying active and doing the work that is expected of you were also seen as strategies to deal with WPLI. However, according to Mostert and Oosthuizen (2006), using distracting activities, such as daydreaming and watching more television than usual as well as engaging more in other activities (e.g. sport) to avoid dealing with the problem is found to be an unsuccessful strategy to deal with demanding aspects of the job, and unhelpful in evading negative overspill to the home.

All of the coping strategies discussed above may also be referred to as resources that educators make use of to better cope with the demands that they experience in both their work and personal lives. Recent empirical evidence suggests that demanding aspects in the work or family domain (or both) are mainly related to conflict, but resources such as control and support are related to positive overspill (Geurts \& Demerouti, 2003; Grzywacz \& Marks, 2000). These resources enhance the employee's well-being and help him or her to manage both work and personal life demands. On the one hand, these resources may eradicate the impact of demanding working conditions, and help employees to avoid unnecessary strain. On the other hand, they may improve an employee's motivation and performance (Demerouti, Bakker \& Bulters, 2004a).

\section{Limitations and Recommendations}

Although the research showed promising results, it is also important to note some limitations of this study. The first limitation was regarding the use of a qualitative research design, which made it difficult to obtain co-operation from participating educators because of their limited amount of time. Secondly, the use of a homogeneous sample, namely secondary school educators only from the district in the North West Educational Department made the study's ability to generalise to other education departments in South Africa limited. There were also conceptual limitations regarding the understanding of the words 'interaction' and 'personal life'.
Despite these limitations, this study has important implications for organisations and for future research. It is recommended that the Department of Education, headmasters and educators are made aware of what it means for work and personal life to be integrated and to be made aware of the consequences of leading an unbalanced life. Furthermore, it is recommended that work-oriented interventions (e.g. teaching educators to deal more effectively with experienced demands from their work and personal lives) and secondary-level interventions (e.g. time management, conflict resolution techniques and coping strategies) be implemented to improve the relationship between educators and the workplace (school).

The most important recommendation for future research is that a quantitative study is done designing an assessment instrument using the qualitative information obtained in this study as a basis. It is recommended that this instrument focusses on helping individuals to create a healthy balance between their work and personal lives by determining which strategies are actually effective in dealing with WPLI. Further, it is also recommended that future research must focus more on a longitudinal design. Information from partners, adolescents, children or supervisors could also be used to gain new insights and perspectives on the relationship between work, personal life and coping. Finally, future research must focus on all of the cultural and language groups in South Africa. Apart from this, future research must be directed at cross-national comparative studies.

\section{AUTHOR'S NOTE}

The material described in this article is based upon work supported by the National Research Foundation under reference number 20050801000025.

\section{REFERENCES}

Aldwin, C.M., \& Revenson, T.A. (1987). Does coping help? A re-examination of the relation between coping and mental health. Journal of Personality and Social Psychology, 53(2), 337345.

Allen, T.D., Herst, D.E., Bruck, C.S., \& Sutton, M. (2000). Consequences associated with work-to-family conflict: A review and agenda for future research. Journal of Occupational Health Psychology, 5(2), 278-308.

Beehr, T.A., Johnson, L.B., Nieva, R., \& Hurrell, J.J. (1995). Occupational stress: Coping of police and their spouses. Journal of Organizational Behavior, 16(1), 3-28.

Beutell, N.J., \& Greenhaus, J.H. (1983). Integration of home and non-home roles: Women's conflict and coping behaviour. Journal of Applied Psychology, 68(3), 43-48.

Brink, B., \& De la Rey, C. (2001). Work-family interaction strain: Coping strategies used by successful women in the public, corporate and self-employed sectors of the economy. South African Journal of Psychology, 31(4), 55-61.

Burke, R.J. (2004). Work and family integration. Equal Opportunities International, 23(1/2), 1-5.

Carlson, D.S., \& Kacmar, K.M. (2000). Work-family conflict in the organization: Do life role values make a difference? Journal of Management, 26(5), 1031-1054.

Carlson, D.S., \& Perrewe, P.L. (1999). The role of social support in the stressor-strain relationship: An examination of workfamily conflict. Journal of Management, 25(4), 513-540.

Carnicer, M.P.D.L., Sánchez, A.M., \& Pérez, M.P. (2004). Workfamily conflict in a Southern European country. Journal of Managerial Psychology, 19(5), 466-489.

Crooker, K.J., Smith, F.L., \& Tabak, F. (2002). Creating work-life balance: A model of pluralism across life domains. Human Resource Development Review, 1(4), 387-419.

De Vos, A.S., Strydom, H., Fouché, C.B., Poggenpoel, M., \& Schurink, E. (1998). Research at grassroots: A primer for the caring professions. Pretoria: Van Schaik.

Demerouti, E., Bakker, A.B., \& Bulters, A.J. (2004a). The loss spiral of work pressure, work-home interference and exhaustion: Reciprocal relations in a three-wave study. Journal of Vocational Behavior, 64(1), 131-149. 
Demerouti, E., Geurts, S.A.E., \& Kompier, M. (2004b). Positive and negative work-home interaction: Prevalence and correlates. Equal Opportunities International, 23(1/2), 6-35.

Demerouti, E., Geurts, S.A.E., Bakker, A.B., \& Euwema, M. (2004c). The impact of shiftwork on work-home conflict, job attitudes and health. Ergonomics, 47(9), 987-1002.

Duxbury, L. (2004). Dealing with work-life issues in the workplace: Standing still is not an option. Kingston, Ontario: Industrial Relations Centre.

Eby, L.T., Casper, W.J., Lockwood, A., Bordeaux, C., \& Brinleya, A. (2005). Work and family research in IO/OB: Content analysis and review of the literature (1980-2002). Journal of Vocational Behavior, 66(1), 124-197.

Edwards, J.R., \& Rothbard, N.P. (2000). Mechanisms linking work and family: Clarifying the relationship between work and family constructs. Academy of Management Review, 25(1), 178-199.

Endler, N.S., \& Parker, J.D.A. (1990). Multidimensional assessment of coping: A critical evaluation. Journal of Personality and Social Psychology, 58, 844-854.

Folkman, S., \& Lazarus, R.S. (1988). Ways of coping questionnaire: Permission set, manual, test booklet, scoring key (Research edn.) California: Mind Garden.

Frone, M.R. (2003). Work-family balance. In J.C. Quick \& L.E. Tetrick (Eds.), The handbook of occupational health psychology. Washington, DC: American Psychological Association.

Geurts, S.A.E., \& Dikkers, J.S.E. (2002, May). The work-nonwork interface: What do we know and where should we go? Paper presented at the European Academy of Management Conference, Stockholm, Sweden.

Geurts, S.A.E., \& Demerouti, E. (2003). Work/non-work interface: A review of theories and findings. In M.J. Schabracq, J.A.M Winnubst \& C.L. Cooper (Eds.), Handbook of work and health psychology. Chichester: Wiley.

Geving, A.M. (2007). Identifying the types of student and teacher behaviours associated with teacher stress. Teaching and Teacher Education, 23(5), 624-640.

Giorgi, A. (1985). Sketch of a psychological phenomenological method. In A. Giorgi (Ed.), Phenomenology and psychological research. Pittsburgh: Duquesne University Press.

Greenhaus, J., \& Beutell, N. (1985). Sources of conflict between work and family roles. Academy of Management Review, 10, $76-88$.

Grzywacz, J.G., \& Marks, N.F. (2000). Reconceptualizing the work-family interface: An ecological perspective on the correlates of positive and negative spillover between work and family. Journal of Occupational Health Psychology, 5(1), $111-126$.

Guba, E.G. (1981). Criteria for assessing the trustworthiness of naturalistic inquiries. Educational Resources Information Centre Annual Review Paper, 29, 75-91.

Hill, E., Miller, B., Weiner, S., \& Colihan, J. (1998). Influences of the virtual office on aspects of work and work/life balance. Personnel Psychology, 51(3), 667-684.

Horn, G. (2006). Educational solutions to improve the employability of senior high school learners. South African Journal of Education, 26(1), 113-128.

Howard, W.G., Donofrio, H., \& Boles, J.S. (2004). Interdomain work-family, family-work conflict and police work satisfaction. Policing: An International Journal of Police Strategies \& Management, 27(3), 380-395.

Jackson, L., \& Rothmann, S. (2006). Occupational stress, organisational commitment, and ill-health of educators in the North West Province. South African Journal of Education, 26(1), 75-95.

Kelly, R., \& Voydanoff, P. (1985). Work-family role strain among employed parents. Family Relations, 34(3), 367-374.

Kerlinger, F.N. (1986). Foundations of behavioral research. (3rd edn.). Fort Worth: Harcourt Brace College.

Kirchmeyer, C. (1993). Nonwork-to-work spillover. A more balanced view of the experiences and coping of professional women and men. Sex Roles, 28, 531-552.
Kirrane, M., \& Buckley, F. (2004). The influence of support relationships on work-family conflict: Differentiating emotional from instrumental support. Equal Opportunities International, 23(1/2), 78-96.

Kossek, E.E., \& Ozeki, C. (1998). Work-family conflict, policies, and the job-life satisfaction relationship: A review and directions for organizational behaviour-human resources research. Journal of Applied Psychology, 83, 139-149.

Kowalski, K.C., \& Crocker, P.R.E. (2001). Development and validation of the Coping Function Questionnaire for adolescents in sport. Journal of Sport and Exercise Psychology, 23(2), 136-155.

Krefting, L. (1991). Rigor in qualitative research: The assessment of trustworthiness. The American Journal of Occupational Therapy, 45(3), 214-222.

Lazarus, R.S., \& Folkman, S. (1984). Stress, appraisal, and coping. New York: Springer.

Lewis, S., \& Cooper, C. (2005). Work-life integration: Case studies of organizational change. Chichester: John Wiley.

Lincoln, Y.S., \& Guba, E.A. (1985). Naturalistic inquiry. London: Sage.

Marais, J.L. (1992). Faktore wat stres veroorsaak by onderwysers in die Oranje-Vrystaat en Kaapprovinsie. Suid-Afrikaanse Tydskrif vir Opvoedkunde, 12(3), 205-309.

Marais, P., \& Meier, C. (2004). Hear our voices: Student teachers' experiences during practical teaching. African Education Review, 1(2), 220-233.

Matsui, T., Ohsawa, T., \& Onglatco, M.L. (1995). Work-family conflict and the stress-buffering effects of husband support and coping behavior among Japanese married working women. Journal of Vocational Behavior, 47(2), 178-192.

Montgomery, A., Mostert, K., \& Jackson, L. (2005a). Burnout and health of primary school educators in the North West Province. South African Journal of Education, 25(4), 266-272.

Montgomery, A.J., Panagopoulou, E.P., Peeters, M.C.W., \& Schaufeli, W.B. (2005b). The meaning of work and home. Community, Work and Family, 8(2), 141-161.

Mostert, K. (2006, April). Work-home interaction research in South Africa: Measurement, prevalence and the relationship with wellbeing. Paper presented at the South African Positive Psychology Conference, Potchefstroom, South Africa.

Mostert, K., \& Oosthuizen, B. (2006). Job characteristics and coping strategies associated with negative and positive work-home interference in a nursing environment. South African Journal of Economic and Management Sciences, 9(4), $429-443$.

Myburgh, C.P.H., \& Poggenpoel, M. (2002). Teachers' experience of their school environment - implications for health promotion. Education, 123, 260-268.

Niehaus, L., Myburgh, C.P.H., \& Kok, J.C. (1995). Selfhandhawingsvermoë van hoërskoolonderwysers. SuidAfrikaanse Tydskrif vir Opvoedkunde, 15(2), 71-78.

Nollen, S.D. (1986). Business programs for work-family problems. Labour Law Journal, 37(8); 480-484.

O'Driscoll, M.P., Brough, P., \& Kalliath, T.J. (2004). Work/ family conflict, psychological well-being, satisfaction and social support: A longitudinal study in New Zealand. Equal Opportunities International, 23(1/2), 1-5.

Olivier, M.A.J., \& Venter, D.J.L. (2003). The extent and causes of stress in teachers in the George region. South African Journal of Education, 23(3), 186-192.

Pei, W., \& Guoli, Z. (2007). Survey of occupational stress of secondary and elementary school teachers and the lessons learned. Chinese Education and Society, 40(5), 32-39.

Pienaar, J., \& Rothmann, S. (2003). Coping strategies in the South African Police Service. South African Journal of Industrial Psychology, 29(4), 81-90.

Repetti, R.L. (1989). Effects of daily workload on subsequent behaviour during marital interaction: The roles of social withdrawal and spouse support. Journal of Personality and Social Psychology, 57(4), 651-659.

Rothmann, J.C., Gerber, J.J., Lubbe, M.S., Sieberhagen, G.v.d.M., \& Rothmann, S. (1998). Pharmacy students' experiences of the contents of pharmacy education: A phenomenological study. The International Journal of Pharmacy Practice, 6, 30-37. 
Rotondo, D.M., Carlson, D.S., \& Kincaid, J.F. (2002). Coping with multiple dimensions of work-family conflict. Personnel Review, 32(3), 275-296.

Schulze, S., \& Steyn, T. (2007). Stressors in the professional lives of South African secondary school educators. South African Journal of Education, 27(4), 619-707.

Shaw, C. (1999). A framework for the study of coping, illness behaviour and outcomes. Journal of Advanced Nursing, 29(5), 1246-1255.

Small, S., \& Riley, D. (1990). Towards a multidimensional assessment of work conflict into family life. Journal of Marriage and the Family, 52(1), 56-61.

Steward, M., \& Donald, F.M. (2006). Spouses' experiences of their partners' absences due to frequent business travel. South African Journal of Psychology, 36(1), 103-125.

Struwig, F.W., \& Stead, G.B. (2001). Planning, designing and reporting research. Cape Town: Pearson Education.

Tighe, M. (2007, 3 April). Stress drives teachers to quit. Sunday Times, p.3.

Toth, H. (2005). Gendered dilemmas of work-life balance in Hungary. Women in Management Review, 20(5), 361-375.
Van Wyk, L. (2004). The relationship between procrastination and stress in the life of the high school teacher. Unpublished masters dissertation, University of Pretoria, Pretoria, South Africa.

Vandeyar, S. (2003). The jagged paths to multicultural education: International experiences and South Africa's response in the new dispensation. South African Journal of Education, 23(3), 193-198.

Wallis, T., \& Price, L. (2003). The relationship between workfamily conflict and central life interests amongst single working mothers. South African Journal of Industrial Psychology, 29(1), 26-31.

Warren, J.A., \& Johnson, P.J. (1995). The impact of workplace support on work-family role strain. Family Relations, 44(2), 163-169.

Weiss, R.S. (1990). Bringing home work stress. In J. Eckenrode \& S. Gore (Eds.), Stress between work and family. New York: Plenum Press.

Woods, N.F., \& Catanzaro, M. (1988). Nursing research: Theory and practice. St Louis: Mosbey. 